Research Article

\title{
Characterization of a Smelting Furnace in Ungyo Site in Wanju, Jeollabuk-do, Through Slag Analysis
}

\author{
Su Jeong Lee ${ }^{1}$, Nam Chul $\mathrm{Cho}^{2,}$, Byoung Sun $\mathrm{Kang}^{3}$ \\ ${ }^{I}$ Chungnam Cultural Heritage Association, Yesan 32432, Korea \\ ${ }^{2}$ Department of Cultural Heritage Conservation Science, Kongju University, Gongju 32588, Korea \\ ${ }^{3}$ Honam Cultural Property Research Center, Damyang 57371, Korea
}

\begin{abstract}
Received July 13, 2019
Revised July 25, 2019

Accepted August 02, 2019

*Corresponding author

E-mail: nam1611@kongju.ac.kr

Phone: +82-41-850-8541

Journal of Conservation Science 2019;35(4):373-383

https://doi.org/10.12654/JCS.2019.

35.4.09

pISSN: 1225-5459, eISSN: 2287-9781

(c) The Korean Society of Conservation Science for Cultural Heritage

This is an Open-Access article distributed under the terms of the Creative Commons Attribution Non-Commercial License (http://creativecommons.org/ licenses/by-nc/3.0) which permits unrestricted non-commercial use, distribution, and reproduction in any medium, provided the original work is properly cited.
\end{abstract}

ABSTRACT We characterized the smelting process and smelting furnace through scanning electron microscopy-energy dispersive spectroscopy, wavelength dispersive X-ray fluorescence, X-ray diffraction, and raman micro-spectroscopy with 13 relics including slags and furnace walls excavated from square-shaped building sites and pits of the Three Kingdoms site at the Ungyo site section I. Our results revealed that the principal components were $\mathrm{FeO}$ and $\mathrm{SiO}_{2}$; and $\mathrm{CuO}, \mathrm{PbO}$, and $\mathrm{ZnO}$ were contained in small quantities. Furthermore, fayalite, magnetite, augite, copper, and cuprite were found. High contents of $\mathrm{FeO}$ or $\mathrm{SiO}_{2}$ components seem to have been added to form fayalite to remove gangue in the smelting process. The relatively low content of $\mathrm{S}$ detected in the copper prills suggests that roasting was performed well. Cristobalite and mullite, which are minerals that indicate high-temperature found in the furnace wall, show that the smelting temperature was higher than $1,250^{\circ} \mathrm{C}$. The findings of this study show a high possibility that the Wanju Ungyo site is smelting remains of copper ores, which are nonferrous metals, rather than iron. Various smelting byproducts excavated in this area in the future will help us better understand the copper smelting process that may have been performed since ancient times.

Key Words Copper smelting, Slag, Furnace wall, Ungyo site, Copper

\section{INTRODUCTION}

Recently, there has been an increasing interest in the science of archaeometallurgy in South Korea, and ancient production techniques and skill levels are being investigated via metallurgical analysis. In modern times, metal products have high value, as a measure of the national technology level (Kang et al., 2010).

Copper is an example of a metal that has been used by mankind for a very long time and is still currently used in a variety of fields. Copper ores have been smelted since approximately 3,800 BC(Lee, 1998; Kwon, 2001). Natural copper was the first metal used by ancient civilizations. Tools were produced using copper via quarrying, crushing, and heat treatment processes without any special reduction process. Later, copper ore in oxide states such as malachite and azurite was used to produce metals via reduction using heat treatment (Kim et al., 2015).

In South Korea, there has been limited research on the ancient mining of copper, compared to gold, silver, or iron. Thus, mining and dressing are not well-understood, which are the basis of cooper smelting research(Kim et al., 2015). 
There are several examples of remains related to copper production in South Korea including the Gyeongju Dongcheon-dong and the Gyeongju Hwangnam-dong 376 remains. Copper smelting and bronze alloy furnaces, copper crucibles, and slags were found in these locations, confirming that copper processing and smelting were performed independently in the Korean Peninsula(Kwon, 2001; Yun et al., 2014; Kim et al., 2015).

Copper smelting experiments were conducted by Yun et al. (2014) in 2013 and 2014, in which the components and microstructure of the byproducts generated in each smelting step were investigated using copper pyrites. However, domestic research on copper smelting has not been widely conducted because smelting remains related to copper are rarely found.

The Wanju Ungyo site in Jeollabuk-do was first excavated in 2010, and various relics from the Paleolithic age to the Joseon dynasty were investigated. Jeollabuk-do is a region where various bronze artifacts have been discovered, suggesting that they likely produced bronze ware. It has been suggested in the literature that many natural copper mines existed in the Geum river basin, and they have been presumed to be traditional diggings related to the exile group of Gojoseon(Jeon, 2004; Han, 2015).

Therefore, in this studyl), to examine the characteristics of the Wanju Ungyo site and the ancient smelting process, the microstructures, compounds, and chemical composition of 13 slags and furnace walls excavated in the Ungyo site were examined. In addition, raman micro-spectroscopy was performed to accurately identify the microstructure and to provide the basic data required to identify the copper smelting technique that was used.

\section{STATUS OF RESEARCH OBJECTS}

\subsection{Remains}

The Wanju Ungyo site is located at San-137, Yongheung-ri, Yongjin-myeon, Wanju-gun, Jeollabuk-do, and the altitude of the surface of the survey area is $25-40 \mathrm{~m}$. The excavation survey

1) This paper re-analyzed and supplemented the slag provided in the analysis report(Honam Cultural Property Research Center, 2013) of Wanju Ungyo remains excavation slag analysis report within the section of Ungyo site, Wanju: Jeonju Jurisdiction National Highway Alternative Bypass(Yongjeong-YongJin). discovered a variety of artifacts including an occupation layer of the Paleolithic age, a Songkukri-type dwelling and jar coffins of the Bronze age, pottery workshop facilities and tombs of the Three Kingdoms period, a stone chamber tomb of the Unified Silla period, and a tile kiln of the Joseon dynasty(Honam Cultural Property Research Center, 2013).

The sites where the research objects were excavated are square-building sites No. 2, 6, and 8, and pit No. 6 in section I. There are 9 square-building sites of the Three Kingdoms period in section I. A variety of relics including pits, ground building sites, post holes, and gullies were identified with almost no duplication, in the alluvial area(Figure 1). The surveyed square-building sites appear to have played the role of a central part of the pottery workshop facilities, and are surrounded by square-shaped external gullies. Multiple post holes square lines were found inside the external gullies, suggesting that a structure was built in this area. The most well-preserved square-building site, No. 8, reveals that there was a furnace inside the square-shaped central post hole line, and it is suggested that there was a path for discharging leftovers from the furnace to the external gullies(Honam Cultural Property Research Center, 2013).

\section{ANALYSIS OBJECTS AND METHOD}

\subsection{Analysis objects}

This study analyzed a total of 13 samples that consisted of 11 slags excavated from square-building sites(No. 2, 6, and 8) and pit No. 6 of the Three Kingdoms period in section I of the Ungyo site, in addition to two furnace walls excavated from the internal pit of square-building site No. 8(Table 1 , Figure 2).

\subsection{Analysis method}

For principal component analysis and compound analysis of the 11 slags and 2 furnace walls, the samples were collected and powdered. They were then analyzed using wavelength dispersive X-ray fluorescence Spectroscopy (WD-XRF)(S4 Pioneer, Bruker, DEU) and an X-ray diffraction system (XRD) (X'pertPRO MPD, Philips, NLD). Principal component analysis and compound analysis were not performed for Slag 9 because it was not possible to acquire sufficient quantity for 


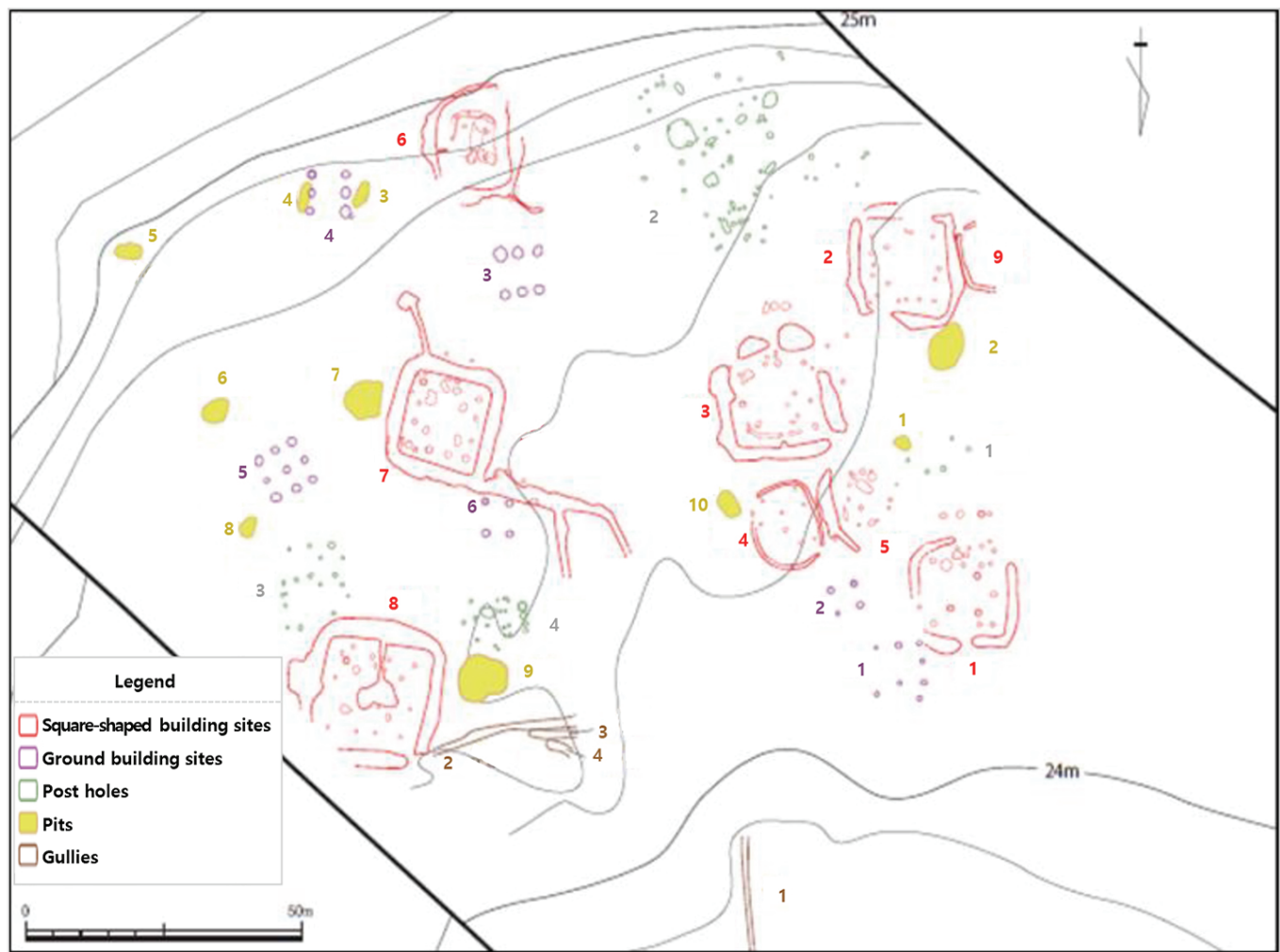

Figure 1. Location relationship of the square-shaped building site from the period of Three Kingdom of Korea in Wanju Ungyo site section I(Honam Cultural Property Research Center, 2013).

Table 1. Features of the analyzed samples from the Ungyo site

\begin{tabular}{|c|c|c|}
\hline Sample & Location & Feature \\
\hline Slag 1 & No. 2 square-shaped building site & Green corrosion products partly observed \\
\hline Slag 2 & No. 6 square-shaped building site & $\begin{array}{l}\text { Liquid type slag, green corrosion products partly } \\
\text { observed }\end{array}$ \\
\hline Slag 3 & \multirow{2}{*}{$\begin{array}{c}\text { No. } 6 \text { square-shaped building site } \\
\text { inside the pit }\end{array}$} & Green corrosion products partly observed \\
\hline Slag 4 & & Green corrosion products partly observed \\
\hline Slag 5 & No. 6 pit & $\begin{array}{l}\text { Smooth surface and trace of flow observed, } \\
\text { green corrosion products partly observed }\end{array}$ \\
\hline Slag 6 & $\begin{array}{l}\text { No. } 8 \text { square-shaped building site } \\
\text { East side gully(North side) }\end{array}$ & Hard and green particles observed \\
\hline Slag 7 & \multirow{2}{*}{$\begin{array}{l}\text { No. } 8 \text { square-shaped building site } \\
\text { East side gully(South side) }\end{array}$} & Easily crumbles and mixed with quartz \\
\hline Slag 8 & & Green corrosion products partly observed \\
\hline Slag 9 & $\begin{array}{l}\text { No. } 8 \text { square-shaped building site } \\
\text { East side gully upper layer }\end{array}$ & Hard, dense and cross-section has a glassy texture \\
\hline Slag 10 & \multirow{2}{*}{$\begin{array}{l}\text { No. } 8 \text { square-shaped building site } \\
\text { East side gully lower layer }\end{array}$} & Green particles observed \\
\hline Slag 11 & & Green particles observed \\
\hline Furnace Wall 12 & \multirow[b]{2}{*}{$\begin{array}{l}\text { No. } 8 \text { square-shaped building site } \\
\text { inside the pit }\end{array}$} & Slag is attached on the other side of the furnace wall \\
\hline Furnace Wall 13 & & $\begin{array}{l}\text { The color becomes darker with movement from the } \\
\text { outer surface towards the inside where the slag is } \\
\text { attached }\end{array}$ \\
\hline
\end{tabular}



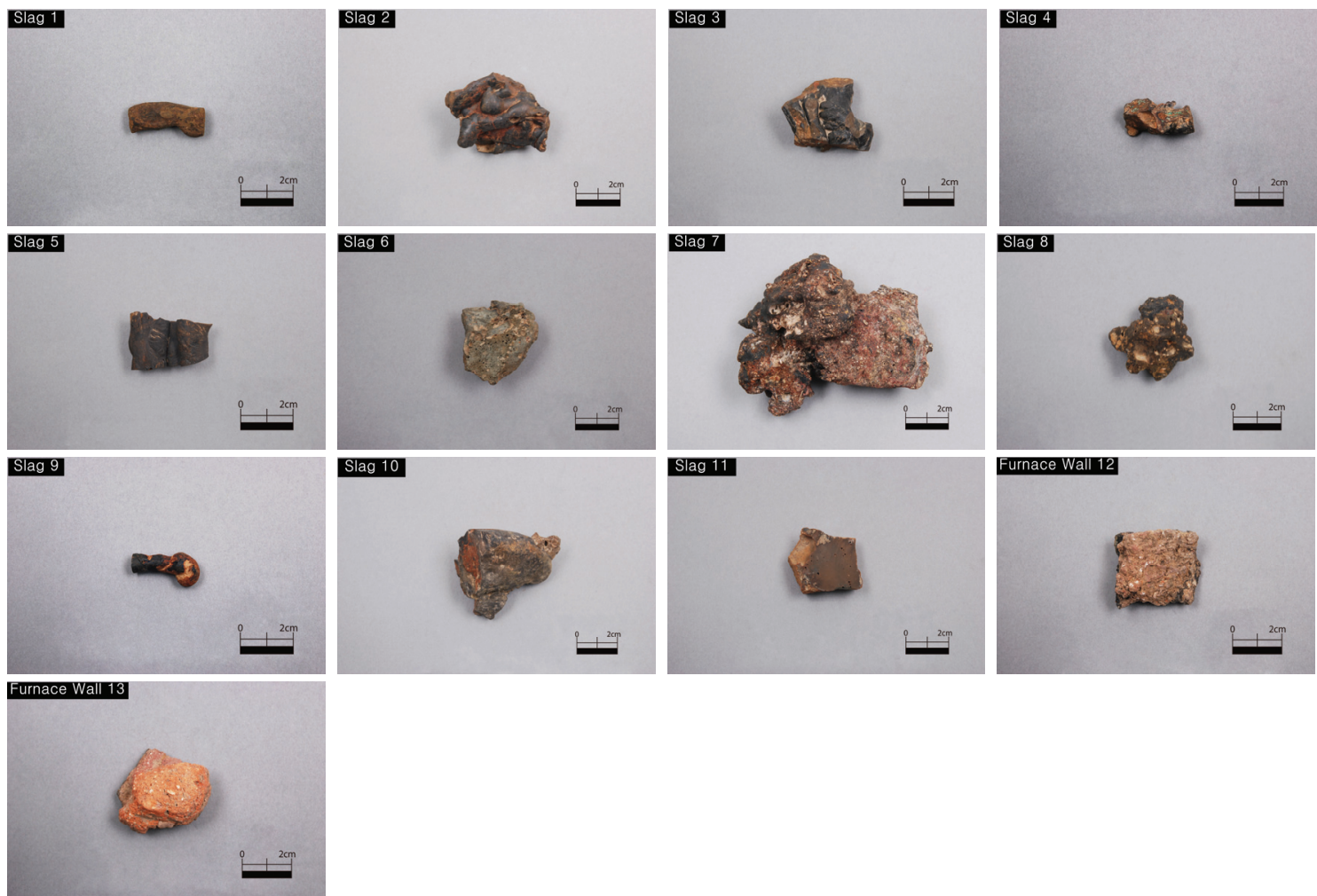

Figure 2. Images of the analyzed samples from the Ungyo site.

analysis. The slags attached to the furnace wall[(Slag 12(2), Slag 13(2)] were separated from the walls(Furnace Wall 12, Furnace Wall 13) and compound analysis was performed.

For microstructure analysis, the samples mounted with epoxy resin were sequentially polished from 200 mesh to 4000 mesh, followed by fine polishing using an abrasive(DP-Spray $3 \mu \mathrm{m}, 1 \mu \mathrm{m}$, Struers, USA). The microstructure was observed using a metallographic microscope(DM 2500M, Leica, DEU). In addition, the sample's surface was platinum-coated and fine microstructures were observed using a Scanning Electron Microscope (SEM)(MIRA3, TESCAN, CZE). The chemical composition of the microstructures was analyzed using an Energy Dispersive Spectrometer (EDS)(QUANTA300, Bruker, DEU).

The platinum coating was removed from the sample for microstructure observation. To accurately identify the microcrystals of the slag, they were analyzed using raman micro-spectroscopy(Lab Aramis, Horiba Jobin Yvon, FRA; He-Ne laser $633 \mathrm{~nm}$ ). The intensity of the laser was reduced and the exposure time was increased to minimize the damage to the sample.

\subsection{Analysis result}

\subsubsection{Chemical composition}

To examine the chemical composition of the analyzed sample, composition analysis was performed using WD-XRF (Table 2). The results revealed that the principal components are $\mathrm{FeO}$ and $\mathrm{SiO}_{2}$, and $\mathrm{Al}_{2} \mathrm{O}_{3}, \mathrm{CaO}, \mathrm{CuO}, \mathrm{ZnO}$, and $\mathrm{PbO}$ are contained in small quantities. It was rare to find $\mathrm{PbO}$ and $\mathrm{ZnO}$ in iron slags associated iron manufactured in South Korea. However, trace elements in PPM units have been detected in iron ores(Jungwon National Research Institute of Cultural Heritage, 2014). The $\mathrm{CuO}, \mathrm{PbO}$, and $\mathrm{ZnO}$ content of slags excavated in the Wanju Ungyo site were analyzed to be 1.77$19.56 \mathrm{wt} \%$, $\mathrm{PbO} 0.16-1.29$ wt\%, and $\mathrm{ZnO} 0.47-5.72$ wt\%, respectively. Thus, the remains seem to be associated with smelting using copper ores containing zinc and copper.

The $\mathrm{CaO}$ content of the Ungyo site slags ranged from $1.62 \mathrm{wt} \%$ at the minimum to $15.69 \mathrm{wt} \%$ at the maximum. The slags attached to the furnace wall exhibited a higher $\mathrm{CaO}$ content than the furnace wall. Until now, the presence of $\mathrm{CaO}$ suggested the possible use of lime to form slag(Lee et al., 2015). 
Table 2. Major chemical composition of slag and furnace wall excavated from the Ungyo site in Wanju

\begin{tabular}{|c|c|c|c|c|c|c|c|c|c|c|c|c|}
\hline \multirow{2}{*}{ Sample } & \multicolumn{12}{|c|}{ Chemical composition (wt\%) } \\
\hline & $\mathrm{FeO}$ & $\mathrm{SiO}_{2}$ & $\mathrm{Al}_{2} \mathrm{O}_{3}$ & $\mathrm{CaO}$ & $\mathrm{CuO}$ & $\mathrm{ZnO}$ & $\mathrm{PbO}$ & $\mathrm{MgO}$ & $\mathrm{K}_{2} \mathrm{O}$ & Mno & $\mathrm{TiO}_{2}$ & $\mathrm{SrO}$ \\
\hline Slag 1 & 41.61 & 37.11 & 7.20 & 6.93 & 2.86 & 1.27 & 0.41 & 1.23 & 1.17 & 0.20 & - & - \\
\hline Slag 2 & 42.34 & 36.40 & 6.75 & 8.48 & 1.77 & 1.46 & 0.35 & 1.20 & 0.81 & 0.19 & 0.22 & 0.02 \\
\hline Slag 3 & 41.92 & 36.65 & 6.07 & 8.23 & 2.47 & 1.25 & 0.35 & 1.35 & 1.26 & 0.20 & 0.25 & - \\
\hline Slag 4 & 38.14 & 34.78 & 13.65 & 7.24 & 2.94 & 1.19 & 0.52 & - & 1.14 & 0.19 & 0.22 & - \\
\hline Slag 5 & 37.37 & 40.19 & 6.34 & 10.59 & 2.00 & 0.82 & 0.16 & 1.18 & 0.94 & 0.21 & 0.21 & - \\
\hline Slag 6 & 22.94 & 46.28 & 7.59 & 12.08 & 6.10 & 2.56 & 0.27 & 1.12 & 0.90 & 0.17 & - & - \\
\hline Slag 7 & 8.72 & 60.91 & 17.49 & 1.62 & 5.97 & 0.47 & - & 0.87 & 3.22 & - & 0.67 & 0.04 \\
\hline Slag 8 & 33.50 & 25.65 & 6.46 & 4.88 & 19.56 & 5.72 & 1.29 & 2.32 & 0.62 & - & - & - \\
\hline Slag 9 & - & - & - & - & - & - & - & - & - & - & - & - \\
\hline Slag 10 & 24.78 & 41.58 & 8.40 & 12.61 & 7.35 & 2.89 & 0.33 & 0.94 & 0.90 & 0.20 & - & 0.04 \\
\hline Slag 11 & 37.17 & 36.21 & 6.27 & 15.69 & 1.99 & 0.95 & - & 0.65 & 0.82 & 0.25 & - & - \\
\hline Furnace Wall 12(1) & 7.40 & 65.14 & 20.71 & 0.92 & 0.48 & - & - & 10.1 & 3.23 & - & 0.97 & 0.05 \\
\hline Slag 12(2) & 27.45 & 38.21 & 10.90 & 2.70 & 14.87 & 2.30 & 0.35 & 1.02 & 1.91 & - & 0.30 & - \\
\hline Furnace Wall 13(1) & 5.82 & 69.36 & 18.77 & 0.89 & 0.18 & - & - & 1.00 & 3.22 & - & 0.76 & - \\
\hline Slag 13(2) & 11.86 & 54.41 & 13.40 & 3.16 & 11.31 & 1.44 & 0.25 & 0.82 & 2.58 & 0.24 & 0.52 & - \\
\hline
\end{tabular}

However, previous studies on smelting experiments and byproducts using copper pyrites revealed that the content of $\mathrm{CaO}$ and calcinated copper pyrites in the effluent and furnace internal materials were $0.71-15.42 \mathrm{wt} \%$ and $2.05 \mathrm{wt} \%$, respectively. Thus, the $\mathrm{CaO}$ content is higher than that of the copper pyrites but the smelting experiment was performed without adding a slag former. Therefore, it is considered that $\mathrm{CaO}$ was included in the effluent and furnace internal materials by the charcoal charged as fuel(Yun et al., 2014). As such, the high $\mathrm{CaO}$ content of the slags excavated at the Ungyo site could have originated from the charcoal charged as fuel as well as from the lime that was added.

\subsubsection{Crystal structure analysis}

$\mathrm{XRD}$ analysis was performed for the slag and furnace wall to evaluate the crystal structure of the analyzed slags (Figure 3).

The main component of slag is fayalite or augite. In addition, magnetite, quartz, copper, and cuprite were also identified. Smelting slags are characterized by the detection of fayalite as the main phase, coexisting with glassy, or via the detection of wüstite(Yoon, 1986; Bae, 2018). Therefore, the slags of the Ungyo site can be determined to be smelting materials. The augite detected in the slags is a silicate mineral containing calcium, magnesium, and aluminum. It appears in a high $\mathrm{CaO}$ content and seems to be one of the gangue components(Lee, 2017). The quartz detected in some slags appear to be non-melted gangue components.

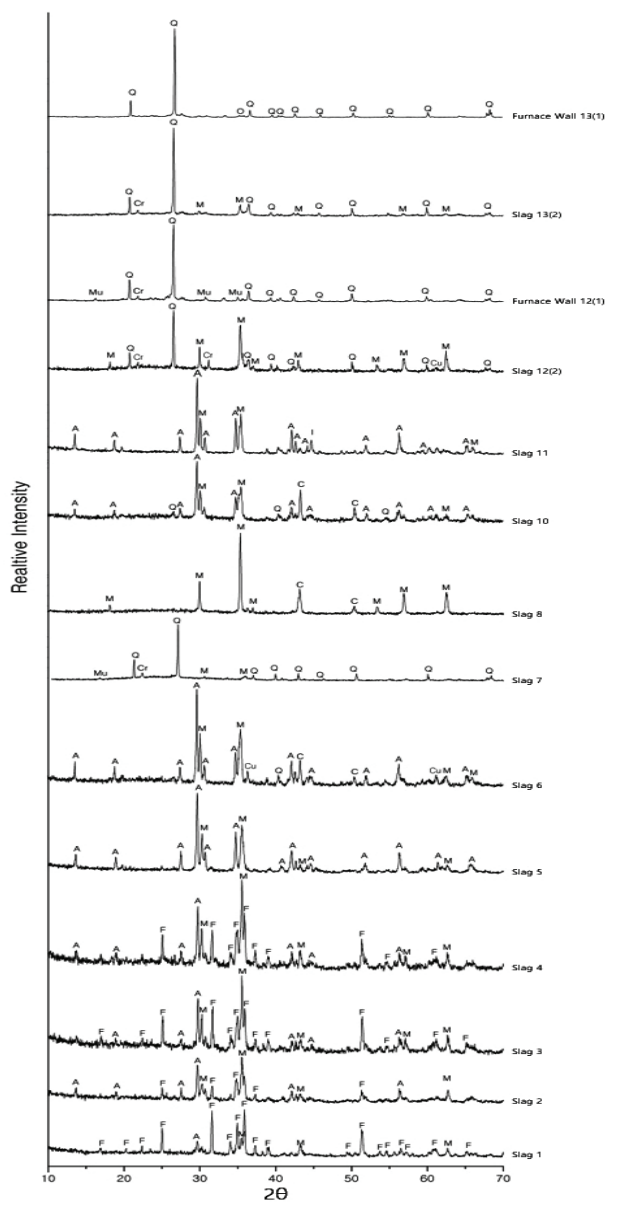

Figure 3. X-ray diffraction patterns of the analyzed Slag 1-13 and Furnace Wall 12-13(A: Augite, M: Magnetite, F: Fayalite, C: Copper, Cu: Cuprite, Cr: Cristobalite, Q: Quartz, Mu: Mullite, I: Iron, O: Olivine). 
The firing temperature inside the furnace can be indirectly estimated via compound analysis of the furnace wall. Quartz was commonly detected in the furnace walls and increasing amounts of cristobalite and mullite. These minerals are indicative of high temperature and were detected from the outside, towards the inside of the furnace wall. Feldspar was melted at $1,250^{\circ} \mathrm{C}$ and needle-shaped secondary mullites were generated. Cristobalites are stable at $1,470-1,728^{\circ} \mathrm{C}$ and are melted above this temperature and become silica glass(Lee and So, 2013). Therefore, it can be reasonable assumed that the temperature of the furnace at the square-building site No. 8 was higher than $1,250^{\circ} \mathrm{C}$.

\subsubsection{Microstructure analysis}

The 13 samples were classified into augite or glass matrix. The augite matrices can be subdivided into a sample with fayalite structure and that without fayalite structure. All samples were characterized by the distribution of copper particles and fine magnetites on a matrix.
Table 3 and Figure 4 show the results of microstructure analysis of Slag 5 and Slag 11, which do not have a fayalite structure on the augite matrix. At positions 4 and 7, the principal components are $\mathrm{FeO}, \mathrm{SiO}_{2}$, and $\mathrm{CaO}$. Thus, it was determined to be augite when compared with the XRD analysis result. At positions 1, 3, 5, and 6, the $\mathrm{FeO}$ content is high and other components are present in trace amounts; thus, it is considered to be magnetite. At position 2, the $\mathrm{CuO}$ content is $95.26 \mathrm{wt} \%$, confirming that they are copper oxide particles.

Table 4 and Figure 5 show the results of microstructure analysis for Slags 1 and 3, which are samples with fayalite structure on an augite matrix. Position 1 corresponds to a structure with a long column shape and is considered to be fayalite with $\mathrm{FeO}$ and $\mathrm{SiO}_{2}$ contents of $60.28 \mathrm{wt} \%$ and 28.61 $\mathrm{wt} \%$, respectively. At positions 2 and 4, the principal components are $\mathrm{FeO}, \mathrm{SiO}_{2}$, and $\mathrm{CaO}$. They are determined to be due to augite, when a comparison is made to the XRD result. At position 3, the $\mathrm{Cl}$ content is $16.80 \mathrm{wt} \%$, which seems

Table 3. EDS results for Slag 5 and Slag 11

\begin{tabular}{cccccccccccc}
\hline \multirow{2}{*}{ Position } & \multicolumn{10}{c}{ Composition (wt\%) } \\
\cline { 2 - 13 } & $\mathrm{Cl}$ & $\mathrm{MgO}$ & $\mathrm{Al}_{2} \mathrm{O}_{3}$ & $\mathrm{SiO}_{2}$ & $\mathrm{~K}_{2} \mathrm{O}$ & $\mathrm{CaO}$ & $\mathrm{FeO}$ & $\mathrm{CuO}$ & $\mathrm{ZnO}$ & $\mathrm{TiO}_{2}$ & $\mathrm{Na}_{2} \mathrm{O}$ \\
\hline 1 & - & 3.14 & 1.85 & 28.61 & 0.24 & 2.19 & 60.28 & - & 1.38 & - & - \\
\hline 2 & - & 0.96 & 8.05 & 36.82 & 1.62 & 13.61 & 33.43 & - & 0.90 & 0.48 & - \\
\hline 3 & 15.87 & - & - & - & - & - & 2.24 & 75.15 & - & - & - \\
\hline 4 & - & 1.80 & 7.53 & 39.98 & 1.06 & 17.34 & 28.99 & 0.52 & - & - & - \\
\hline 5 & - & - & 3.12 & 5.11 & 0.29 & 0.92 & 85.68 & - & - & 1.26 & 0.18 \\
\hline
\end{tabular}

1) '-’: Not detected.
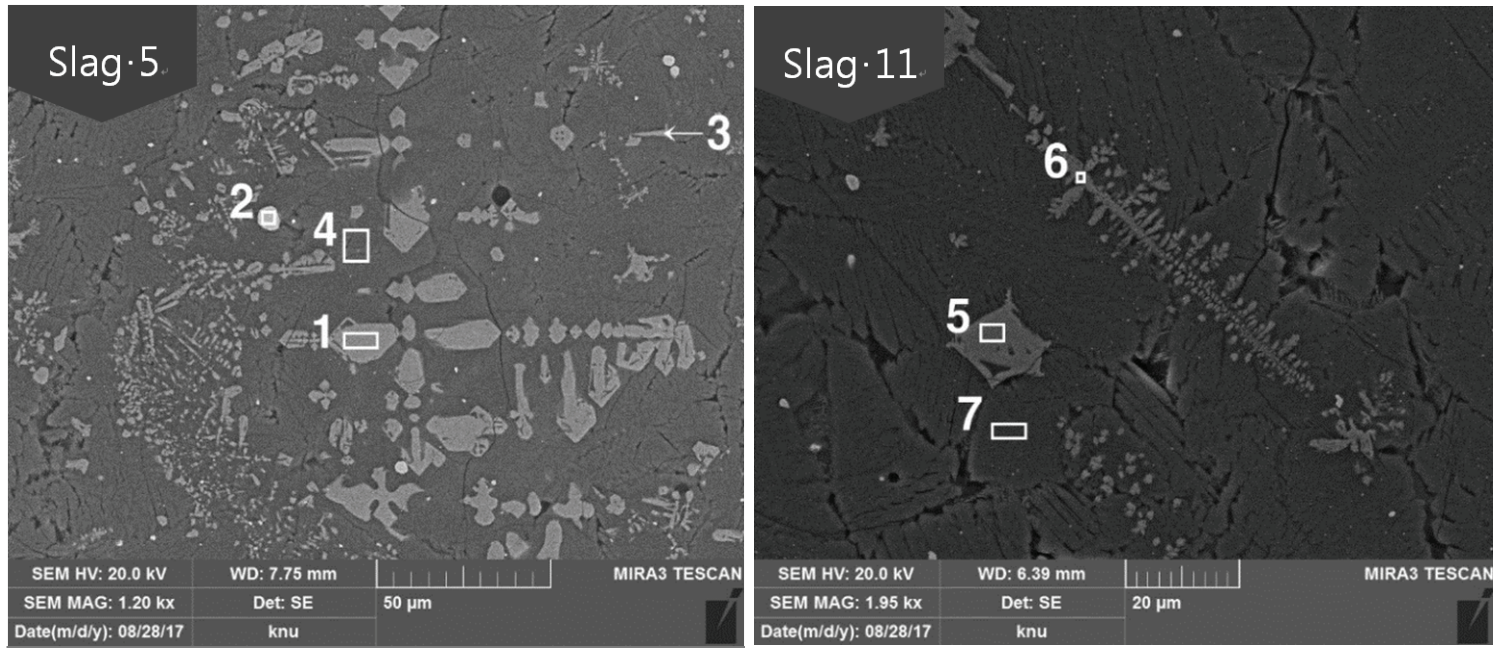

Figure 4. SEM images and points of EDS analysis(Slag 5 and Slag 11). 
Table 4. EDS results for Slag 1 and Slag 3

\begin{tabular}{ccccccccccc}
\hline \multirow{2}{*}{ Position } & \multicolumn{1}{c}{ Composition (wt\%) } \\
\cline { 2 - 12 } & $\mathrm{MgO}$ & $\mathrm{Al}_{2} \mathrm{O}_{3}$ & $\mathrm{SiO}_{2}$ & $\mathrm{~K}_{2} \mathrm{O}$ & $\mathrm{CaO}$ & $\mathrm{FeO}$ & $\mathrm{CuO}$ & $\mathrm{ZnO}$ & $\mathrm{TiO}_{2}$ & $\mathrm{Na}_{2} \mathrm{O}$ \\
\hline 1 & - & 1.70 & - & - & - & 95.26 & - & - & - & - \\
\hline 2 & - & - & - & - & - & 4.53 & 90.80 & - & - & - \\
\hline 3 & - & 2.54 & 7.02 & 0.61 & 1.80 & 83.10 & - & - & 1.22 & - \\
\hline 4 & 1.47 & 8.00 & 44.43 & 1.73 & 16.33 & 21.90 & 1.72 & 0.84 & - & - \\
\hline 5 & - & 2.53 & 1.42 & - & 0.52 & 91.65 & - & - & - & 0.50 \\
\hline 6 & - & 5.51 & 12.57 & 1.39 & 0.82 & 76.54 & - & - & - & - \\
\hline 7 & 1.36 & 6.36 & 38.22 & 1.87 & 20.15 & 28.17 & 1.03 & - & - & - \\
\hline
\end{tabular}

1) '-': Not detected.
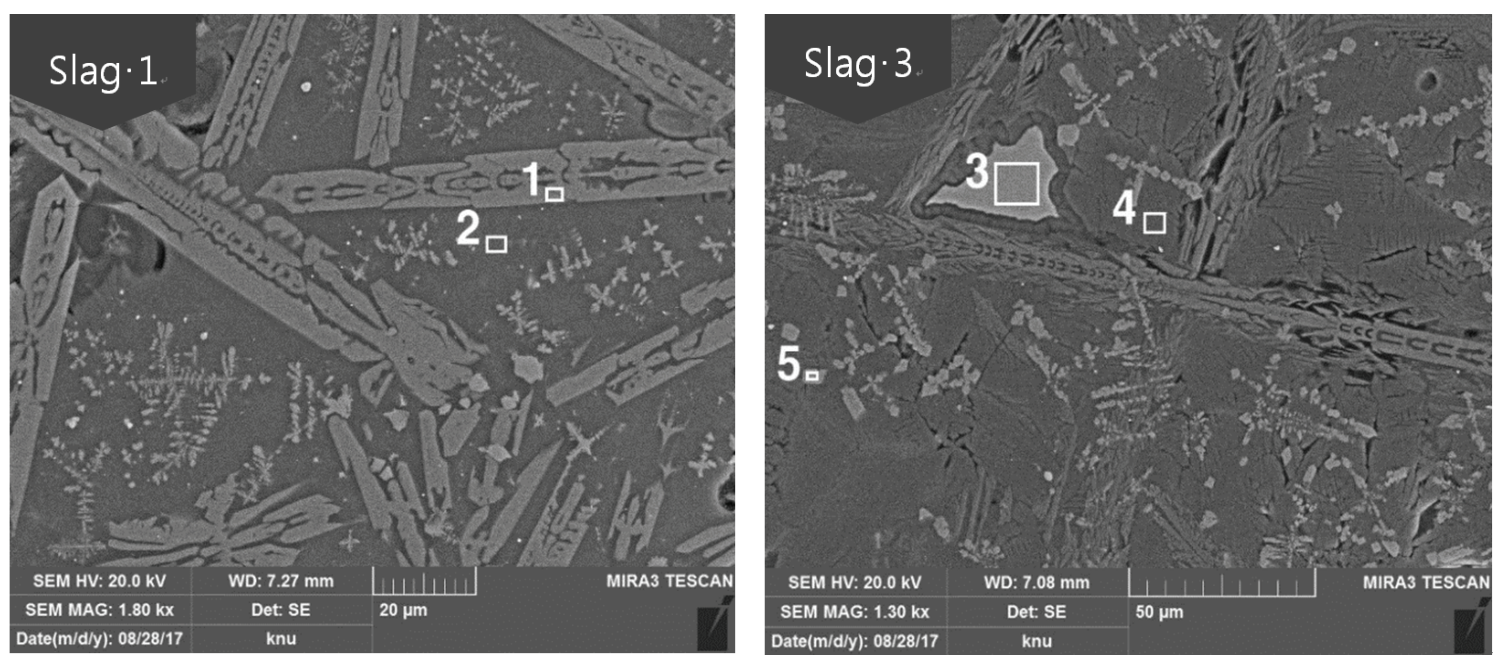

Figure 5. SEM images and points of EDS analysis(Slag 1 and Slag 3).
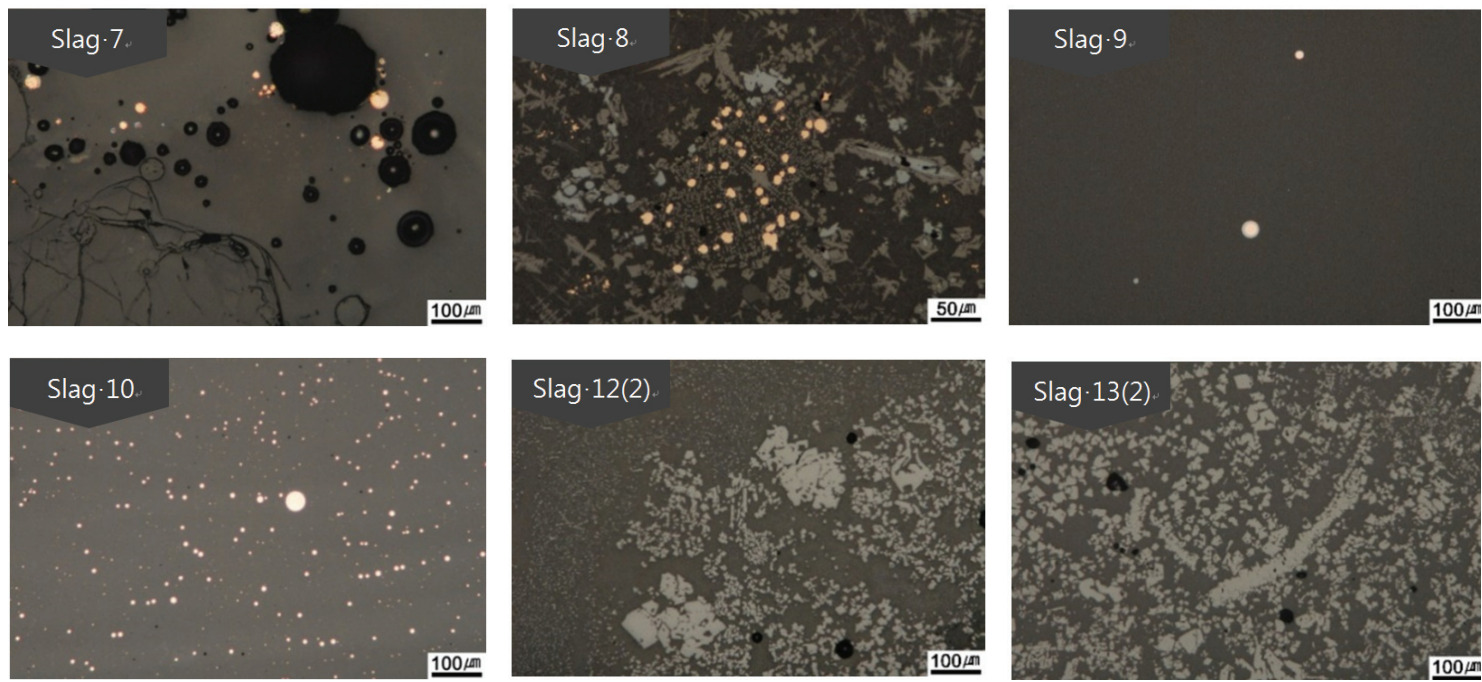

Figure 6. Microstructure of the slag from Slag 7-10, Slag 12(2) and Slag 13(2). 
Table 5. EDS results for Slag 9 and Slag 10

\begin{tabular}{ccccccccccc}
\hline \multirow{2}{*}{ Position } & \multicolumn{10}{c}{ Composition (wt\%) } \\
\cline { 2 - 12 } & $\mathrm{MgO}$ & $\mathrm{Al}_{2} \mathrm{O}_{3}$ & $\mathrm{SiO}_{2}$ & $\mathrm{~K}_{2} \mathrm{O}$ & $\mathrm{CaO}$ & $\mathrm{FeO}$ & $\mathrm{CuO}$ & $\mathrm{ZnO}$ & $\mathrm{SO}_{4}$ & $\mathrm{Na}_{2} \mathrm{O}$ \\
\hline 1 & 1.36 & 4.19 & 17.49 & 0.63 & 5.85 & 16.89 & 31.65 & - & 18.97 & - \\
\hline 2 & 1.89 & 6.86 & 30.85 & 1.77 & 13.61 & 40.39 & - & 1.60 & - & 0.64 \\
\hline 3 & - & 0.66 & 91.83 & - & - & - & - & - & - & - \\
\hline 4 & - & - & - & - & - & 0.83 & 95.43 & - & - & - \\
\hline 5 & 1.41 & 8.38 & 47.02 & 1.59 & 14.50 & 21.94 & - & 1.50 & - & 0.26 \\
\hline
\end{tabular}

1) '-': Not detected.
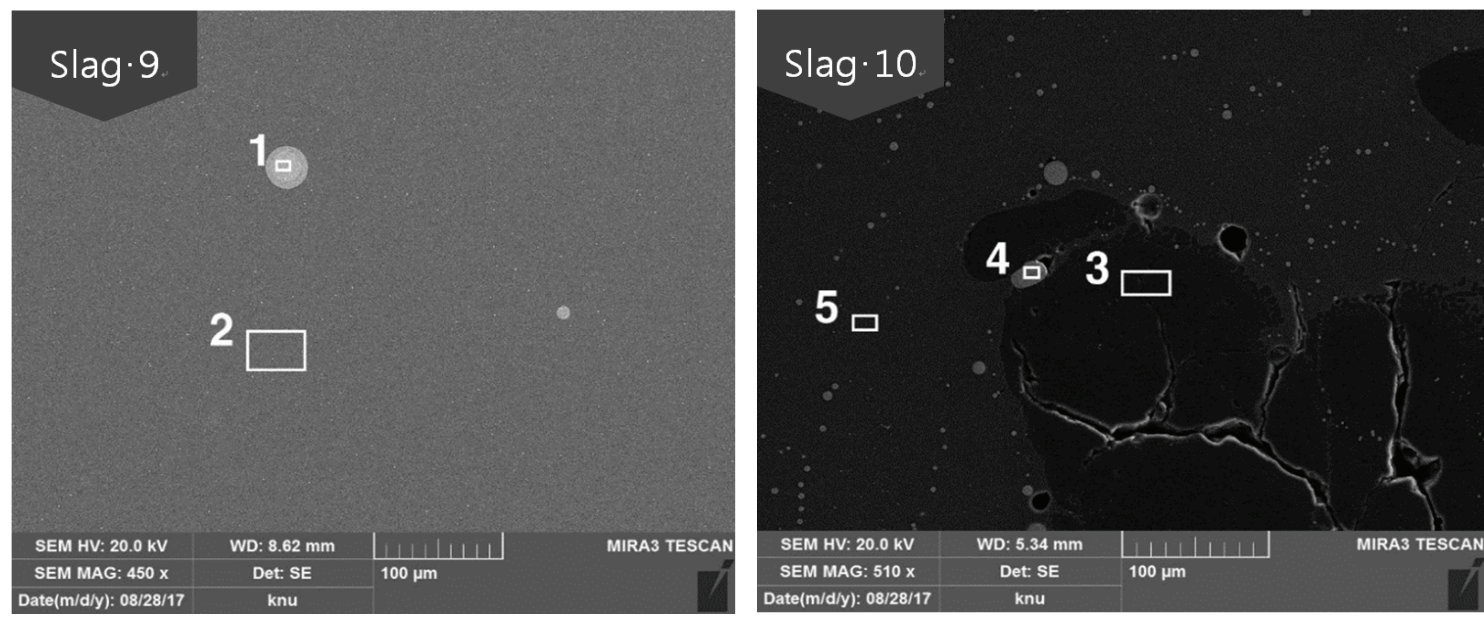

Figure 7. SEM images and points of EDS analysis(Slag 9 and Slag 10).

to have been generated in the oxidation and corrosion process. Position 5 is part of dendritic particles and is considered to be an iron oxide with a $\mathrm{FeO}$ content of $85.68 \mathrm{wt} \%$.

Figure 6 shows the microstructure of a glass matrix sample. The slags excavated in square building No. 8 were all verified to be glassy except for Slag 11, which was excavated in the lower layer of the east side gully. In Slags 7 and 10, unmelted quartz was observed, and pores were observed in all the slags. Table 5 and Figure 7 show the results of the microstructure analysis for Slags 9 and 10, which are the glassy samples. The Slag 9 sample is small and $40.39 \mathrm{wt} \%$ of $\mathrm{FeO}$ was detected at position 2. Thus, it is considered to be a glass matrix that contains a large amount of Fe. Position 1 corresponds to be copper sulfide particles containing $18.97 \mathrm{wt} \%$ of $\mathrm{SO}_{4}$ and position 4 corresponds to be cooper oxide particles containing $95.43 \mathrm{wt} \%$ of $\mathrm{CuO}$. Position 3 corresponds to unmelted quartz particles, and position 5 corresponds to a glass matrix. SEMEDS analysis of the $\mathrm{Cu}$ oxide particles in some slags revealed the presence of $\mathrm{SO}_{4}$, which was not detected by XRF. This may be due to the difference in sampling positions.

\subsubsection{Raman micro-spectroscopy analysis}

Raman micro-spectroscopy was performed to accurately identify the observed micro-crystals based on the chemical composition of the compound and microstructure analyses. The samples were analyzed after the structure observed in the slags were selected and the results were compared with the data in the references(Buzatu and Buzgar, 2010; Luo et al., 2010; Muralha et al., 2011).

Figure 8 shows the result of analyzing the crystalline matrix using raman micro-spectroscopy. The gray structures exhibit raman shifts of $185,315,379,529,659,770,925$, and $1,005 \mathrm{~cm}^{-1}$. Thus, they were determined to be augites. These structures were also observed in the XRD analysis, but it was difficult to confirm their identity via metallographic microscopy observations. However, they could be definitively identified using raman micro-spectroscopy.

Figure 9 shows blue, red, and gray $\mathrm{Cu}$ oxide particles that were observed using the metallographic microscope. Figure 10 shows the result of the analysis via raman micro-spectroscopy. The blue and red $\mathrm{Cu}$ oxide particles were confirmed to be 

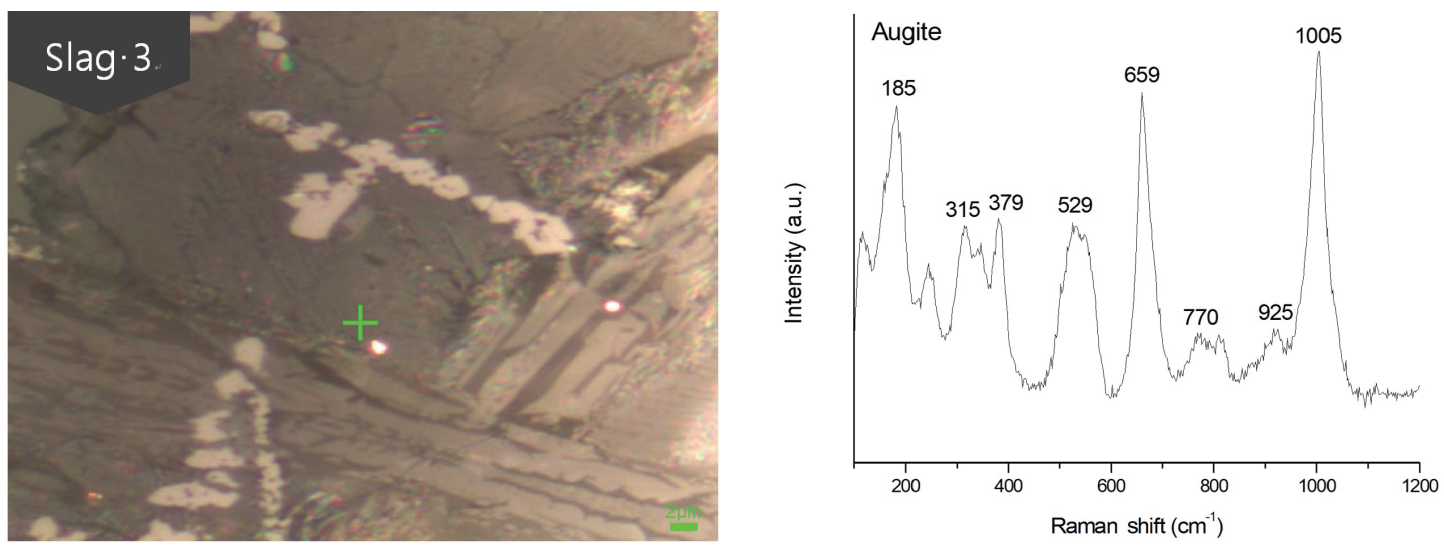

Figure 8. Raman micro-spectroscopy analysis results of Slag 3(augite).

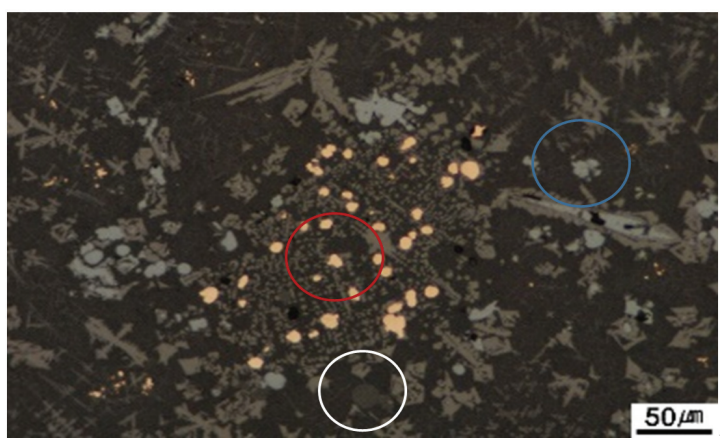

Figure 9. Microstructure of slag 8 with blue, red and gray circles indicating the presence of $\mathrm{Cu}$ oxide particles.

cuprite because they almost match the cuprite raman shift and have similar peak shapes(Figures $10 \mathrm{~A}$ and $10 \mathrm{~B}$ ). The gray $\mathrm{Cu}$ oxide particles almost match the raman shifts of magnetite and atacamite and their peak shapes are similar(Figure 10C). Therefore, they were confirmed to be magnetite and atacamite(Figure 10C). Atacamite was not detected in the XRD analysis but could be detected via raman micro-spectroscopy. Atacamite $\left[\mathrm{Cu}_{2}(\mathrm{OH})_{2} \mathrm{Cl}\right]$ is a secondary mineral of copper that is easily generated in a dry or salt-containing state and is produced together with malachite and cuprite(Sehwa Editorial Department, 2001).

\section{DISCUSSION AND CONCLUSION}

In this study, 13 slags excavated in the Wanju Ungyo site were analyzed. The slags generally exhibited a high content of $\mathrm{FeO}$ and $\mathrm{SiO}_{2}$, and also contained $\mathrm{CuO}, \mathrm{ZnO}, \mathrm{PbO}, \mathrm{Al}_{2} \mathrm{O}_{3}$, and $\mathrm{CaO}$ in small quantities. Therefore, it is considered that the slags were generated not by iron smelting, but by smelting with copper ores, which are nonferrous metals.

The $\mathrm{CaO}$ content of slags was high compared to the furnace wall. This suggests that lime was intentionally added or charged from charcoal during the smelting work in this region.

The result of the XRD result confirmed that the samples were augite, fayalite, and magnetites(e.g., copper, cuprite). When principal component analysis and compound analysis results for the slags were compared, it was determined that augite was present as the principal phase when the $\mathrm{CaO}$ content was higher than approximately $6 \mathrm{wt} \%$, except for Slag 2 .

Based on the compound analysis result of the furnace wall excavated from the internal pits in square-building site No. 8, the existence of cristobalite, which is generated at high temperatures, indicates that the smelting work was performed at temperatures in excess of $1,250^{\circ} \mathrm{C}$.

The microstructures of the slags have a fully vitrified matrix. They are classified into three types of structures: structures with copper particles, structures with fine magnetites, and structures with fine magnetites and copper particles on augite or fayalite structures.

The existence of $\mathrm{SO}_{4}$ in the slag and the detection of zinc and lead components suggest the possibility of smelting using copper sulfate ores that contain zinc and lead.

In summary, the Wanju Ungyo site is highly likely to be the remains of a site where copper was produced using copper sulfate ores containing zinc and lead. However, this site does not provide sufficient information to comprehensively understanding ancient copper smelting techniques on the Korean Peninsula. Additional scientific studies on more remains are required to elucidate the ancient copper smelting techniques in this region. 

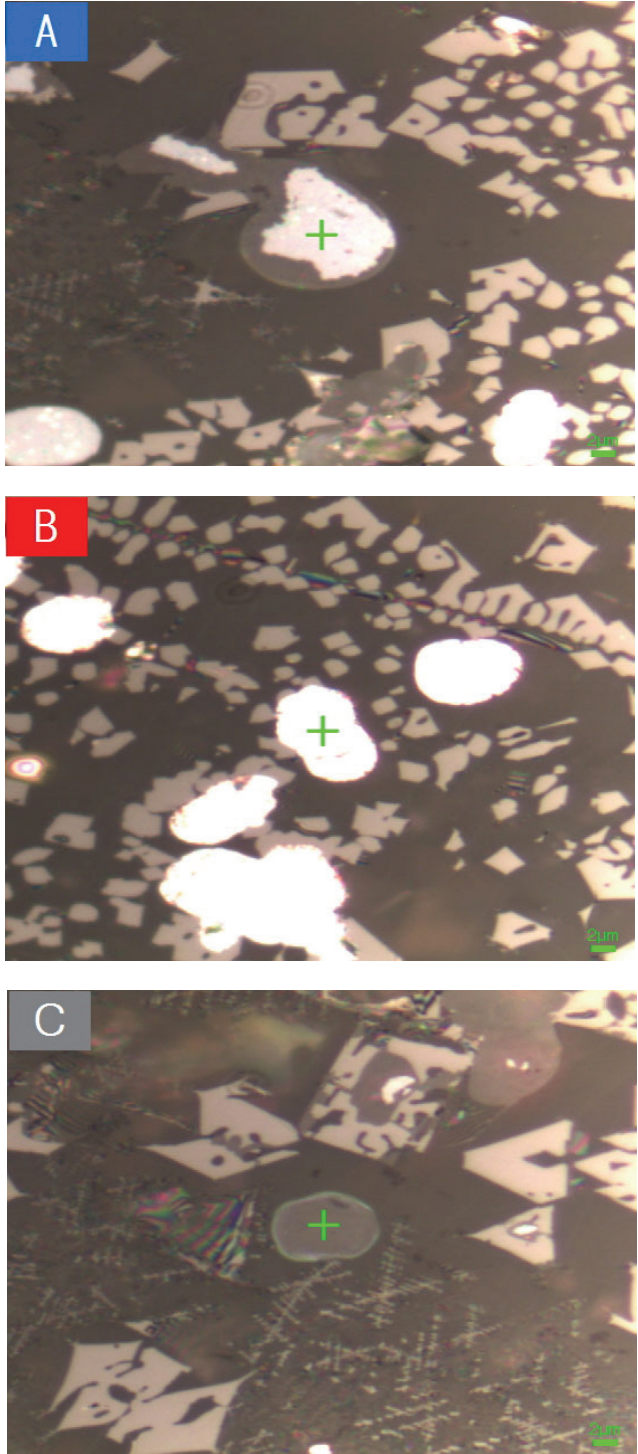
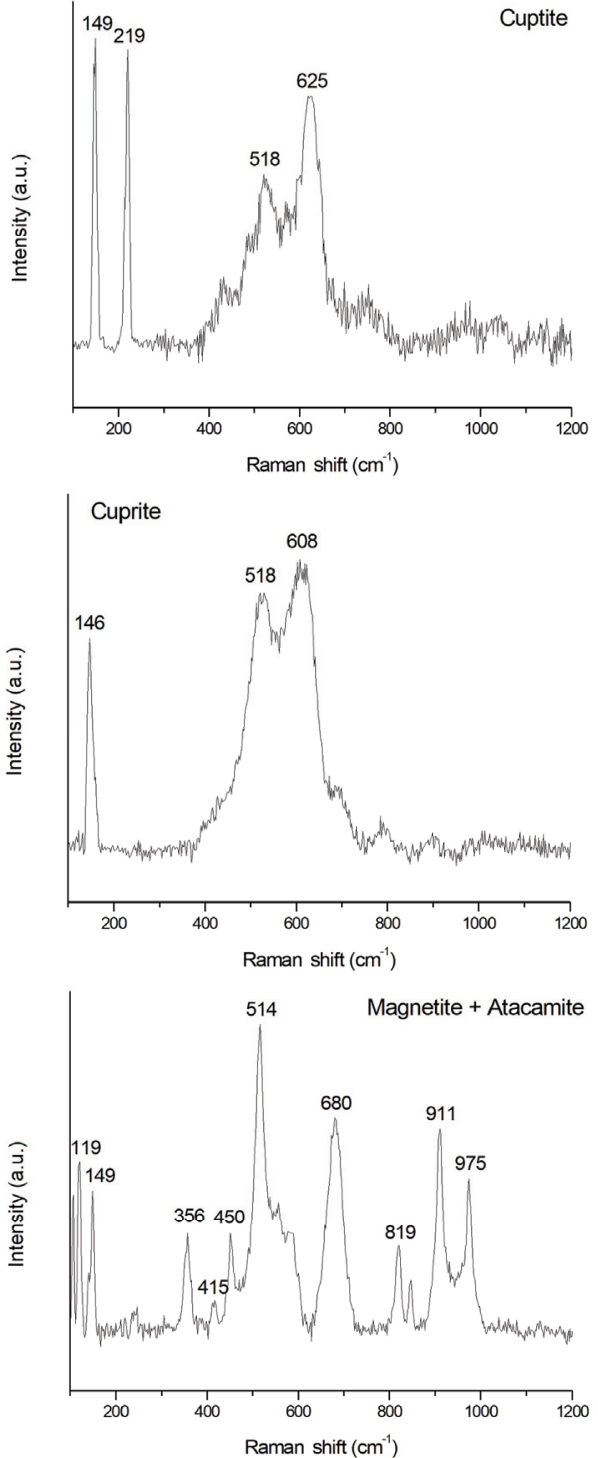

Figure 10. Raman micro-spectroscopy analysis results for Slag 8. (A) $\mathrm{Cu}$ oxide particle of the blue circle in Figure 9, (B) $\mathrm{Cu}$ oxide particle of the red circle in Figure 9 and (C) $\mathrm{Cu}$ oxide particle of the grey circle in Figure 9.

\section{ACKNOWLEDGMENTS}

This work was supported by the Protected Research Support Program of the National Research Foundation of Korea (NRF-2016R1D1A2B03936071).

\section{REFERENCES}

Bae, C.L., 2018, Study on the iron production process through the analysis of by-products excavated from iron smelting site in Bupyeong-ri, Inje, Korea. Master's thesis, Kongju
University, Gongju. (in Korean with English abstract)

Buzatu, A. and Buzgar, N., 2010, The raman study of singlechain silicates. Analele Științifice ale Universității "Alexandru Ioan Cuza" Iași, seria Geologie, 1(1), 108-125.

Honam Cultural Property Research Center, 2013, Wanju Ungyo site. (in Korea)

Han, S.Y., 2015, A study on the early iron age tombs in the Jeonbuk region. Ph.D. dissertation, Chonbuk National University, Jeonju. (in Korean with English abstract)

Jeon, Y.R., 2004, Remarks on the bronze wares cultural area along the basin of the Kum river. Mahan-Baekje Culture, 16, 5-21. (in Korean) 
Jungwon National Research Institute of Cultural Heritage, 2014, Natural science analysis report of excavated artifacts from the Jungwon area. (in Korean)

Kang, Y.H., Cho, N.C., Song, H.J. and GO, H.S., 2010, The study on material characteristics of slags excaved from iron making site. Journal of Conservation Science, 26(2), 171-182. (in Korean with English abstract)

Kim, S.J., Lee, E.U., Hwang, J.J. and Han, U.R., 2015, A literature review on ancient smelting technology and sites of copper. Korean Journal of Cultural Heritage Studies, 48(4), 126-137. (in Korean with English abstract)

Kwon, H.N., 2001, The study on ancient copper smelting: Slags excavated from dongchun-dong, Kyungju. Master's thesis, Kookmin University, Seoul. (in Korean with English abstract)

Lee, B.H. and So, M.G., 2013, Compositional and microstructural analyses of grayish-blue-powdered celadon in Yeongseo region in Gangwon-do: By Wonju Beopcheontemple site. Analytical Science \& Technology, 26(3), 211221. (in Korean with English abstract)

Lee, S.I., 1998, Nonferrous metal smelting engineering. Munundang. Seoul. (in Korean)

Lee, E.U., Lee, J.J., Chae, M.H. and Kim, E.J., 2015, Examination of smelting and smithing slags excavated from the iron production site of the Nogye village. Journal of Conservation Science, 31(4), 411-427. (in Korean with English abstract)
Lee, Y.N., 2017, Metallurgical study on the by-products of the iron smelting excavated from Jinwi region in Pyeongtaek. Master's thesis, Kongju University, Gongju. (in Korean with English abstract)

Luo, W.G., Qin, Y., Huang, F. and Wang, C., 2010, Analysis of the corrosion products of the ancient bronzes excavated from Qiaojiayuan tombs. Applied Physics Research, 2(2), 156-169.

Muralha, V.S.F., Rehren, T. and Clark, R.J.H., 2011, Characterization of an iron smelting slag from Zimbabwe by raman microscopy and electron beam analysis. Journal of Raman Spectroscopy, 42(12), 2077-2084.

Sehwa Editorial Department, 2001, Chemical dictionary. (in Korea)

Yoon, D.S., 1986, On the slag produced in early iron metallurgy. The Journal of the National Academy of Science, 25, 280-390. (in Korean with English abstract)

Yun, Y.H., Cho, N.C., Yoon, D.S., Jang, S.B., Jeong, Y.S. and Lee, E.C., 2014, The smelting experiment using chalcopyrite and analysis study of by-products. Journal of the Institute of Bibliography, 60, 287-311. (in Korean with English abstract) 
